\title{
FACTSHEET
}

rightsandresources.org

\section{Who Owns the Land in Africa? Formal recognition of community-based land rights in Sub-Saharan Africa}

The question of who owns the world's lands and natural resources is a major source of contestation around the globe, affecting prospects for rural economic development, human rights and dignity, cultural survival, political stability, conservation of the environment, and efforts to combat climate change. To inform advocacy and action on community land rights, RRI has published Who Owns the World's Land? A global baseline of formally recognized indigenous $\mathbb{E}$ community land rights ("the global baseline"), ${ }^{1}$ which identifies the amount of land national governments have formally recognized as owned or controlled by Indigenous Peoples and local communities across 64 countries constituting 82 percent of global land area. The report focuses on community-based tenure regimes, which include any system where formal rights to own or manage land or terrestrial resources are held at the community level, including lands held under customary tenure regimes.
This brief summarizes findings on community ownership and control of lands in the 19 countries (identified below) in Sub-Saharan Africa that were included in the global baseline.

\section{Key findings:}

- Only 16 percent of the total land of the countries studied in Sub-Saharan Africa is owned or controlled by Indigenous Peoples and local communities, compared with 18 percent globally.

- All 19 countries studied in Sub-Saharan Africa have enacted laws to enable the recognition of community ownership or control of land; however, implementation of these laws is often weak or nonexistent.

- In eight of the 19 countries, Indigenous Peoples and local communities own or control less than 1 percent of the country's land area, including both agricultural and forested lands.

\section{Role of community-based tenure in Sub-Saharan Africa}

A large share-one study estimates up to 60 percent-of national land area in Sub-Saharan Africa is held under customary or traditional forms of land ownership in practice. Nevertheless, national governments do not formally recognize communities' rights to much of this land.

When communities manage natural resources, those resources can be a source of significant economic and livelihood benefits. For example, in 2009, communitymanaged nature conservancies in Namibia generated
US $\$ 3.7$ million and provided direct and indirect employment for more than 1600 people through the maintenance of the conservancies and the associated tourist trade. ${ }^{2}$ Only about 10 percent of these jobs were supported by international assistance. A study of people in Zimbabwe who use communal areas estimated that the poorest 20 percent of the population studied relied on communal areas for approximately 40 percent of their household income, including from many livelihood activities largely undertaken by women. 


\section{Results for Sub-Saharan Africa}

The global baseline identified two broad categories of formal recognition of community-based tenure regimes: "ownership" where communities have a stronger set of land rights; and "control" where governments place significant restrictions on communities but do recognize some key rights, such as the right to manage their lands or the right to exclude outsiders from community lands.

The percent of land area held in nationally recognized community-based tenure regimes in the 19 countries studied in Sub-Saharan Africa lagged behind the global figures (see Figure 1). Local communities and Indigenous Peoples owned 10 percent and controlled an additional 8 percent of the global land area studied. By contrast, in the 19 countries studied in Sub-Saharan Africa, communities owned only 3 percent and controlled an additional 13 percent of land area.

All 19 of the African countries studied have enacted laws to recognize some type of community-based tenure regime; however, a large number of countries provide little or no formal recognition of Indigenous Peoples' and local communities' rights to own or control specific lands (see Table). In eight of the 19 countries, Indigenous Peoples and local communities own or control less than 1 percent of the country's land area, including both agricultural and forested lands. For example, the governments of the Democratic Republic of the Congo (DRC) and the Central African Republic (CAR) have laws in place for the recognition of community forest concessions in the DRC and community forests and collective forests in the CAR; however, no lands have been designated for communities under these tenure regimes.

Africa also has the highest number of countries where national statutes recognize the rights of communities to own or control more than half of the country's land area: Tanzania (75 percent), Uganda (67 percent), Zambia (53 percent), and Botswana (53 percent). Four additional Sub-Saharan African countries recognize community-based ownership or control of more than 25 percent of their countries' land area: Zimbabwe (42 percent), Namibia (41 percent), Liberia (32 percent), and Mozambique (26 percent). Nevertheless, implementation continues to be a challenge, even in countries with high percentages of community-based tenure recognition.

In Tanzania, Uganda, and Zambia, the high percentage of community-based tenure recognition reflects the fact that national laws automatically recognize all customary community lands without requiring communities to register their lands. This automatic recognition reduces procedural requirements that can be burdensome and deter communities from formalizing their land rights.

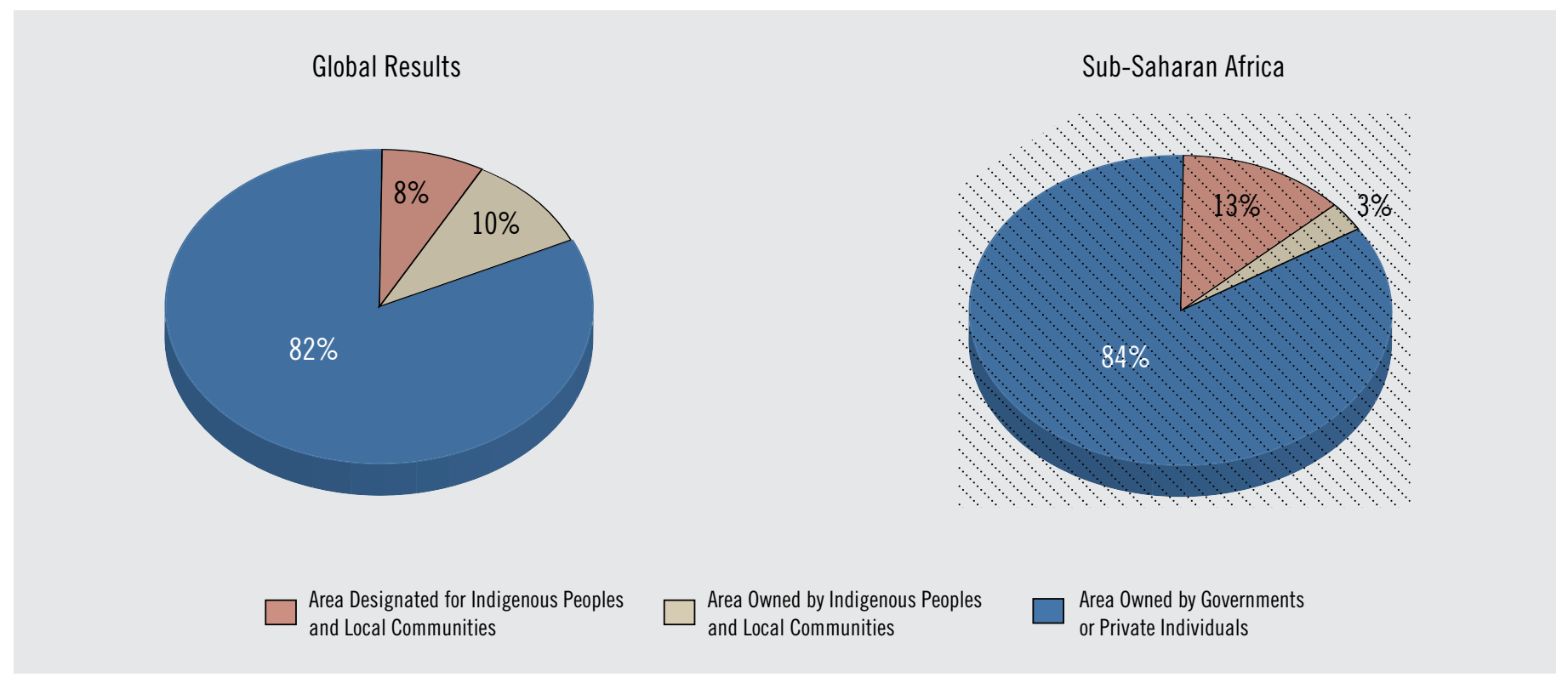

Figure 1: Comparing Results 


\begin{tabular}{|c|c|c|c|c|c|c|c|c|c|c|}
\hline \multirow{2}{*}{\multicolumn{2}{|c|}{ Country }} & \multirow[b]{2}{*}{$\begin{array}{l}\text { Total Country } \\
\text { Area (Mha) }\end{array}$} & \multicolumn{2}{|c|}{$\begin{array}{l}\text { Designated for } \\
\text { Indigenous Peoples and } \\
\text { Local Communities }\end{array}$} & \multicolumn{2}{|c|}{$\begin{array}{l}\text { Owned by Indigenous } \\
\text { Peoples and Local } \\
\text { Communities }\end{array}$} & \multicolumn{2}{|c|}{$\begin{array}{l}\text { Total Area Designated for or } \\
\text { Owned by Indigenous Peoples } \\
\text { and Local Communities }\end{array}$} & \multirow{2}{*}{ 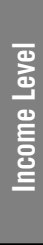 } & \multirow{2}{*}{ 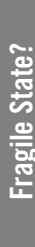 } \\
\hline & & & Area (Mha) & $\begin{array}{l}\text { Percent of } \\
\text { Country Area }\end{array}$ & Area (Mha) & $\begin{array}{l}\text { Percent of } \\
\text { Country Area }\end{array}$ & $\begin{array}{l}\text { Total Area } \\
\text { (Mha) }\end{array}$ & $\begin{array}{l}\text { Total Percent } \\
\text { of Country } \\
\text { Area }\end{array}$ & & \\
\hline \multirow{20}{*}{ 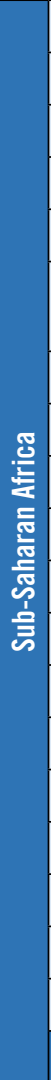 } & Angola & 124.67 & ----- & $0.00 \%$ & 0.01 & $0.00 \%$ & 0.00 & $0.00 \%$ & M & $\mathrm{N}$ \\
\hline & Botswana & 56.67 & 30.29 & $53.44 \%$ & ----- & $0.00 \%$ & 30.29 & $53.44 \%$ & M & $\mathrm{N}$ \\
\hline & Cameroon & 47.27 & 4.26 & $9.02 \%$ & ----- & $0.00 \%$ & 4.26 & $9.02 \%$ & M & $\mathrm{N}$ \\
\hline & Central African Republic (CAR) & 62.30 & 0.00 & $0.00 \%$ & ----- & $0.00 \%$ & 0.00 & $0.00 \%$ & $\mathrm{~L}$ & $Y$ \\
\hline & Chad & 125.92 & No data & $0.00 \%$ & ----- & $0.00 \%$ & 0.00 & $0.00 \%$ & $\mathrm{~L}$ & Y \\
\hline & $\begin{array}{l}\text { Congo, Democratic Republic of } \\
\text { the (DRC) }\end{array}$ & 226.71 & 0.00 & $0.00 \%$ & ----- & $0.00 \%$ & 0.00 & $0.00 \%$ & $\mathrm{~L}$ & $Y$ \\
\hline & Congo, Republic of the & 34.15 & 0.44 & $1.28 \%$ & ----- & $0.00 \%$ & 0.44 & $1.28 \%$ & M & $\mathrm{N}$ \\
\hline & Ethiopia & 100.00 & 0.21 & $0.21 \%$ & ----- & $0.00 \%$ & 0.21 & $0.21 \%$ & L & $\mathrm{N}$ \\
\hline & Gabon & 25.77 & 0.01 & $0.05 \%$ & ----- & $0.00 \%$ & 0.01 & $0.05 \%$ & M & $\mathrm{N}$ \\
\hline & Kenya & 56.91 & 0.21 & $0.37 \%$ & 3.30 & $5.80 \%$ & 3.51 & $6.17 \%$ & $M$ & $\mathrm{~N}$ \\
\hline & Liberia & 9.63 & No data & $0.00 \%$ & 3.06 & $31.73 \%$ & 3.06 & $31.73 \%$ & L & $Y$ \\
\hline & Mozambique & 78.64 & 0.99 & $1.26 \%$ & 19.10 & $24.29 \%$ & 20.09 & $25.54 \%$ & L & $\mathrm{N}$ \\
\hline & Namibia & 82.33 & 33.40 & $40.57 \%$ & ----- & $0.00 \%$ & 33.40 & $40.57 \%$ & M & $\mathrm{N}$ \\
\hline & South Sudan & 64.43 & ----- & $0.00 \%$ & No data & $0.00 \%$ & 0.00 & $0.00 \%$ & L & $Y$ \\
\hline & Sudan & 186.15 & 0.06 & $0.03 \%$ & ----- & $0.00 \%$ & 0.06 & $0.03 \%$ & M & $Y$ \\
\hline & Tanzania & 88.58 & 64.14 & $72.41 \%$ & 2.37 & $2.67 \%$ & 66.51 & $75.08 \%$ & $\mathrm{~L}$ & $\mathrm{~N}$ \\
\hline & Uganda & 19.98 & 0.00 & $0.00 \%$ & 13.45 & $67.30 \%$ & 13.45 & $67.30 \%$ & $\mathrm{~L}$ & $\mathrm{~N}$ \\
\hline & Zambia & 74.34 & 39.21 & $52.74 \%$ & ---- & $0.00 \%$ & 39.21 & $52.74 \%$ & $M$ & $\mathrm{~N}$ \\
\hline & Zimbabwe & 38.69 & 16.40 & $42.39 \%$ & ---- & $0.00 \%$ & 16.40 & $42.39 \%$ & $\mathrm{~L}$ & $Y$ \\
\hline & Region Total & 1503.13 & 189.62 & $12.62 \%$ & 41.27 & $2.75 \%$ & 230.89 & $15.36 \%$ & & \\
\hline & Global Total & 10672.70 & 854.90 & $8.01 \%$ & 1084.71 & $10.16 \%$ & 1939.62 & $18.17 \%$ & & \\
\hline
\end{tabular}

However, where communities' land rights are not spatially delimited and registered, governments must take additional care to ensure that their actions respect customary ownership. For example, in Uganda, both the Constitution and Land Act of 1998 recognize customary law. In practice, however, the government has issued concessions over customary lands without consultation and has not provided customary owners with the compensation or benefit sharing to which they are legally entitled because communities are unable to produce certificates of customary ownership.

Finally, advocacy efforts are needed to encourage African governments to strengthen the quality of rights recognized, because many countries recognize only limited rights for communities to control, rather than own, land. Twelve countries only designate lands for Indigenous Peoples and local communities, five countries have both types of tenure regimes (ownership and control), and two countriesAngola and South Sudan-only have tenure regimes that recognize ownership rights for Indigenous Peoples and local communities, although data on implementation in South Sudan was not available at the time of printing.

\section{Results for Fragile States in Sub-Saharan Africa}

Governments can promote political stability by recognizing communities' land rights and establishing systems to fairly and efficiently resolve disputes over land and natural resources. The dubious legal position of customary land interests played a role in all but three of the 30 plus armed conflicts that took place in Africa between 1990 and 2009. 


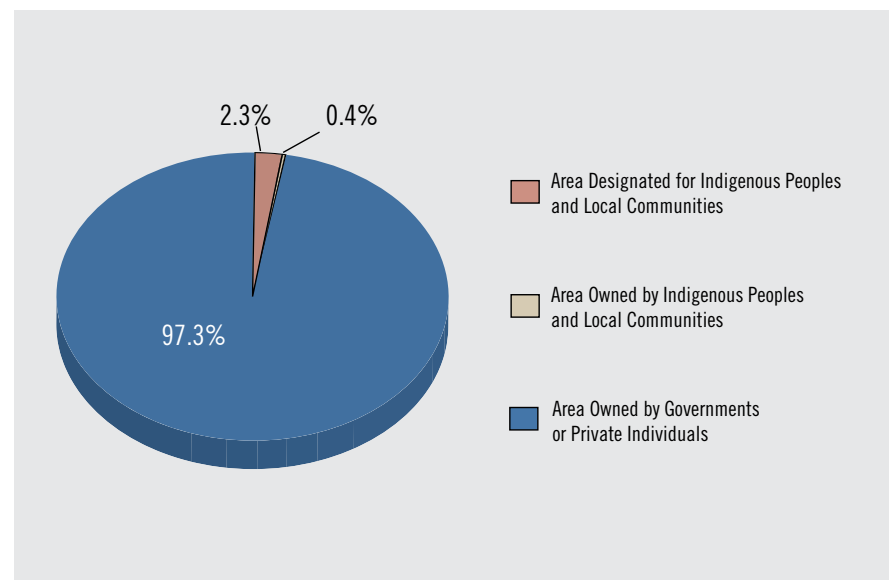

Figure 2: Fragile States in Sub-Saharan Africa

Of the 19 African countries studied, seven were identified by the World Bank as fragile in 2015. Five of the seven countries have experienced either war or minor armed conflict in the past five years (CAR, Chad, DRC, South Sudan, Sudan).

Progress in recognizing community-based land rights is strikingly weak in the fragile states in Sub-Saharan Africa when compared with either the global results or the results for Sub-Saharan Africa (compare Figure 1 with Figure 2). In these fragile states in Sub-Saharan Africa, local communities and
Indigenous Peoples only control 2 percent of the land area, and they own a fraction of one percent of the land.

Fragile states face unique challenges associated with an extreme lack of government capacity; however, peacebuilding and statebuilding can also offer an opportunity to pursue community tenure reform and rebuild government technical and administrative capacity. For example, in Liberia, disputes over land and natural resources related to customary ownership, conflicts between communities, and poor government administration of land and natural resources were among the structural causes of conflict. The Government of Liberia and the international community recognized the importance of addressing land tenure as part of the foundation for a lasting peace, and have taken the opportunity to work towards land reform and the recognition of customary rights (See Box). ...peacebuilding and statebuilding can also offer an opportunity to pursue community tenure reform and technical and administrative capacity. rebuild government

\section{LAND TENURE REFORM IN LIBERIA}

In 2008, Liberia established the National Land Commission and began the process of working towards land reform as part of its broader efforts to achieve lasting peace and stability. In 2013 Liberia enacted a national Land Rights Policy recognizing customary tenure. Now, in 2015, the Liberian legislature is considering a draft Land Rights Act that would recognize customary tenure as a matter of law without requiring titling, using an approach similar to that of Mozambique, Tanzania, Uganda, and Zambia. This would be a significant development because experts estimate that 71 percent of Liberia's land area is held under customary tenure. A significant concern, however, is the status of concessions, as one draft provision states that existing concessions on community land will be honored. Therefore, communities will only be able to exercise their customary rights after concessions expire. This is particularly problematic because estimates indicate that the government has issued concessions over approximately 75 percent of Liberia's land area.

Even to the extent that legislative reforms protect customary tenure, they will not eliminate tenure insecurity without robust procedural requirements and the administrative capacity to identify and respect customary land holdings. Government agencies must be willing and able to coordinate their actions in order to avoid infringements on customary tenure when issuing concessions, designating protected areas, and taking other actions that could adversely affect communities' property rights. Communities across over 30 percent of Liberia's land area have already obtained titles for their customary lands in the form of Public Land Sale Deeds and Aboriginal Land Grant Deeds. Nevertheless, a lack of technical capacity, interagency coordination, and due process has led to instances where titled community lands have been expropriated without compensation to make way for concessions or protected areas. 


\section{Opportunities for Reform and Way Forward}

The global baseline focuses on formal, statutory recognition of customary land tenure because it is a necessary first step for local communities and Indigenous Peoples to achieve tenure security. Several African countries-not just Liberia-are in the process of undertaking legal reforms. In the DRC, the government has issued implementing regulations for Local Community Forestry Concessions, is considering draft legislation on Indigenous Peoples' rights, and has developed a draft decree for the implementation of customary rights. In Kenya, several bills before the parliament have the potential to improve communities' tenure security over land and forests. ${ }^{3}$ The government of Cameroon is also considering land tenure reform; however, its status is not clear. International processes related to climate change and the post-2015 Sustainable Development Goals could also serve as points of entry for the promotion of community-based tenure recognition.

These represent significant opportunities for progress; nevertheless, reforms are still needed in key areas:

- The area formally recognized under statutory law is much less than the area to which Indigenous Peoples and local communities hold customary rights. Further action is needed to bridge that gap.
- In many countries, laws may recognize community control but need to be strengthened to recognize more robust rights of ownership. Even where ownership is recognized, laws or regulations may limit certain uses of the land, particularly for commercial purposes. Incompatible laws governing other sectors such as extractive industries, agribusiness, and conservation can also adversely impact indigenous and community land rights.

- Moreover, formal legal recognition of indigenous and community lands is not sufficient to guarantee tenure security. States and other actors must also respect, support and enforce such legal protections.

The global baseline identifies the current state of community-based tenure recognition and work that still needs to be done to help communities realize their tenure rights. The stakes are high, because ultimately, community-based tenure security will determine whether Indigenous Peoples and local communities have the legal right to manage their lands as they choose-a question that strikes at the heart of rural peoples' daily lives and has major implications for controlling climate change, ensuring food security, reducing political conflict, and protecting the world's remaining natural resources. 


\section{Endnotes}

1 This factsheet was prepared by Ilona Coyle based on the full report: Rights and Resources Initiative. 2015. Who Owns the World's Land? A global baseline of formally recognized indigenous and community land rights. Washington, DC: RRI. http://www. rightsandresources.org/publication/whoownstheland.

2 Kothari, Ashish, Colleen Corrigan, Harry Jonas, Aurélie Neumann, and Holly Shrumm (eds). 2012. Recognising and Supporting Territories and Areas Conserved by Indigenous People and Local Communities: Global Overview and National Case Studies. Technical Series No. 64. Secretariat of the Convention on
Biological Diversity, ICCA Consortium, Kalpavriksh, and Natural Justice, Montreal, Canada. https://www.cbd.int/doc/publications/ cbd-ts-64-en.pdf.

3 Mwathane, Ibrahim. 2015. "Kenya: Some Pending Land Bills and What They Will Fix.” Daily Nation, September 5. http:// allafrica.com/stories/201509070450.html. Government of Kenya. 2015. The Forest Conservation and Management Bill, 2015 (draft dated March 23). http://www.environment.go.ke/wp-content/ uploads/2015/04/Forest-Conservation-and-Management-Bill -2015-23-3-2015.pdf.

For more information on methodology and findings of the full report, please see: http://www.rightsandresources .org/publication/whoownstheland. To preserve the brevity of this summary, citations have been omitted unless they provide new information not discussed in the full report. 



\section{THE RIGHTS AND RESOURCES INITIATIVE}

RRI is a global coalition of 13 Partners and over 150 international, regional, and community organizations advancing forest tenure, policy, and market reforms. RRI leverages the strategic collaboration and investment of its Partners and Collaborators around the world by working together on research, advocacy, and convening strategic actors to catalyze change on the ground.

RRI is coordinated by the Rights and Resources Group, a non-profit organization based in Washington, D.C. For more information, please visit www.rightsandresources.org.

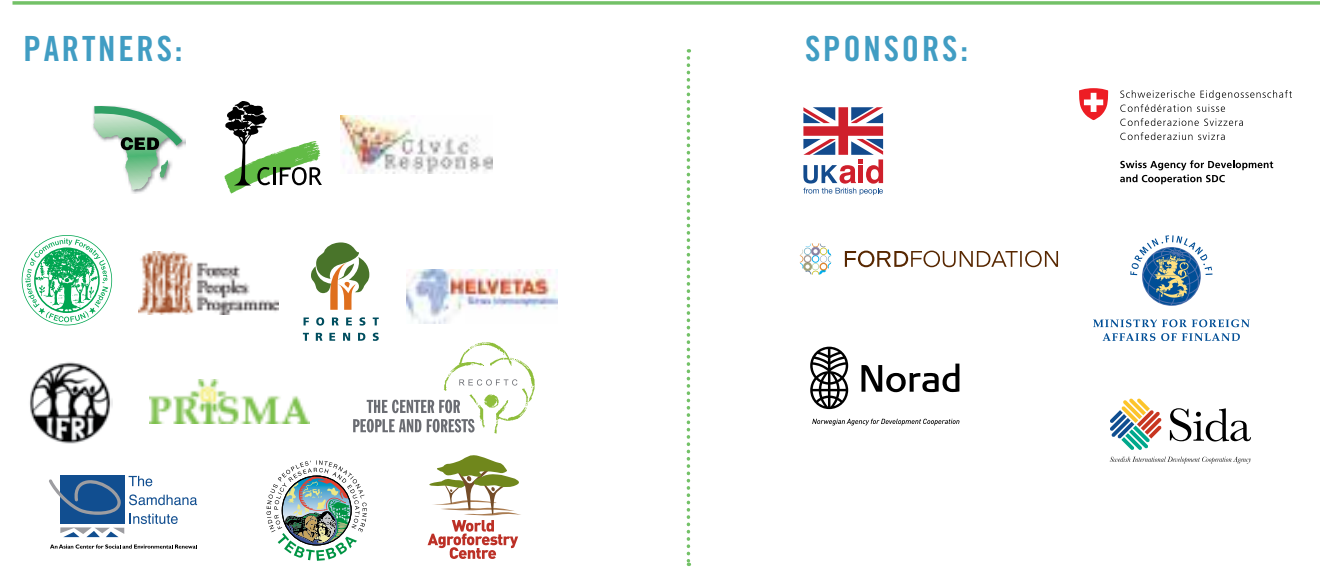

The views presented here are those of the authors and are not necessarily shared by the agencies that have generously supported this work, or all of the Partners of the Coalition.

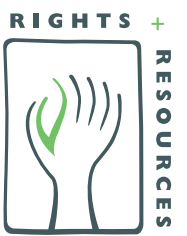

1238 Wisconsin Avenue NW Suite 300

Washington, DC 20007

www.rightsandresources.org 